\title{
Nucleation-Dependent Polymerization Is an Essential Component of Amyloid-Mediated Neuronal Cell Death
}

\author{
Mark Wogulis, Sarah Wright, Damian Cunningham, Tamie Chilcote, Kyle Powell, and Russell E. Rydel \\ Elan Pharmaceuticals, South San Francisco, California 94080
}

Accumulating evidence suggests that amyloid protein aggregation is pathogenic in many diseases, including Alzheimer's disease. However, the mechanisms by which protein aggregation mediates cellular dysfunction and overt cell death are unknown. Recent reports have focused on the potential role of amyloid oligomers or protofibrils as a neurotoxic form of amyloid- $\beta(\mathrm{A} \beta)$ and related amyloid aggregates. Here we describe studies indicating that overt neuronal cell death mediated by $\mathrm{A} \beta_{1-40}$ is critically dependent on ongoing $\mathrm{A} \beta_{1-40}$ polymerization and is not mediated by a single stable species of neurotoxic aggregate. The extent and rate of neuronal cell death can be controlled by conditions that alter the rate of $\mathrm{A} \beta$ polymerization. The results presented here indicate that protofibrils and oligomeric forms of $\mathrm{A} \beta$ most likely generate neuronal cell death through a nucleation-dependent process rather than acting as direct neurotoxic ligands. These findings bring into question the use of the 3-(4,5-dimethylthiazol-2-yl)-2,5-diphenyltetrazolium bromide formazan assay (MTT assay) as a reporter of $\mathrm{A} \beta$-mediated neuronal cell death and suggest that diffusible $\mathrm{A} \beta$ protofibrils and oligomers more likely mediate subtle alterations of synaptic function and long-term potentiation rather than overt neuronal cell death. These results have been extended to $\mathrm{A} \beta_{1-42}$, the non- $\mathrm{A} \beta$ component of Alzheimer's disease amyloid plaques, and human amylin, suggesting that nucleationdependent polymerization is a common mechanism of amyloid-mediated neuronal cell death. Our findings indicate that ongoing amyloid fibrillogenesis may be an essential mechanistic process underlying the pathogenesis associated with protein aggregation in amyloid disorders.

Key words: Alzheimer's disease; amyloid- $\beta$; neurotoxicity; neuronal cell death; nucleation-dependent polymerization; amyloidogenic proteins

\section{Introduction}

Alzheimer's disease (AD) is a progressive neurodegenerative disease characterized by extracellular amyloid plaques, neurofibrillary tangles, neuronal dysfunction, and overt neuronal cell death. A major constituent of amyloid plaques is the 39-43 amino acid amyloid- $\beta(\mathrm{A} \beta)$ protein (Glenner and Wong, 1984), which is constitutively produced by normal cleavage of the membranebound amyloid- $\beta$ precursor protein (Seubert et al., 1992). A variety of evidence suggests that $A \beta$ accumulation is a pathogenic event in Alzheimer's disease. Amyloid- $\beta$-containing extracellular plaques are an early and invariant feature of the disease. All known familial AD mutations lead to increased production or cerebral deposition (Selkoe, 2001) or aggregate state (Nilsberth et al., 2001) of $A \beta$. Furthermore, the levels of soluble $A \beta$ correlate closely with synaptic loss and markers of disease severity (Lue et al., 1999; McLean et al., 1999).

\footnotetext{
Received June 16, 2004; revised Dec. 14, 2004; accepted Dec. 15, 2004.

We thank our many colleagues at Elan Pharmaceuticals for helpful discussions and support throughout the execution of these studies. In particular, we extend our appreciation to Drs. Karen Chen, Stephen Freedman, and Ivan Lieberburg for insightful discussions and their valuable comments on the studies presented here.

Correspondence should be addressed to Dr. Russell E. Rydel, Elan Pharmaceuticals, 800 Gateway Boulevard, South San Francisco, CA 94080. E-mail: russell.rydel@elan.com.

M. Wogulis' present address: Section of Molecular and Cellular Biology, University of California at Davis, One Shields Avenue, Davis, CA 95616.

D. Cunningham's present address: Biogen Idec, 3010 Science Park Road, San Diego, CA 92191.

DOI:10.1523/JNEUROSCI.2381-04.2005

Copyright $\odot 2005$ Society for Neuroscience $\quad$ 0270-6474/05/251071-10\$15.00/0
}

A variety of studies have demonstrated neurotoxicity associated with the treatment of neuronal cultures with aggregated $\mathrm{A} \beta$ (Yankner, 1996) and other amyloidogenic proteins (Caughey and Lansbury, 2003), supporting a pathogenic role for amyloid accumulation in various disease states. Amyloid- $\beta$ neurotoxicity has been shown to correlate with the presence of fibrils or $\beta$-sheet structures (Simmons et al., 1994; Howlett et al., 1995; Seilheimer et al., 1997). However, the mechanisms by which $A \beta$ aggregation mediates neuronal cell death are unknown.

If protein aggregation is a critical component of $A \beta$-mediated pathology, then manipulations that affect the aggregation state of $\mathrm{A} \beta$ should provide insight into these neurotoxic properties. $A \beta$ aggregation has been shown to proceed by a multistep, nucleation-dependent process (Jarrett and Lansbury, 1993). Formation of the nucleation seed is rate limiting, so that, in the absence of preformed seed fibrils, there is a significant lag period for the formation of $\mathrm{A} \beta$ fibrils, followed by a rapid fibril elongation phase once seed fibrils have been generated. The lag time for fibril formation can be dramatically shortened by the addition of preformed fibril seeds to monomer solutions of $\mathrm{A} \beta$ (Jarrett and Lansbury, 1993). The rate of monomer incorporation into polymer increases with both increasing concentration of seed and increasing concentration of monomer (Naiki and Nakakuki, 1996). Therefore, the rate of $A \beta$ fibril formation is controlled by both fibril seed concentration and monomer concentration.

The results presented here demonstrate that treatments with 
fibrillar $\mathrm{A} \beta$ or soluble $\mathrm{A} \beta$ alone are not toxic to primary human or rodent neurons. However, when fibrillar $A \beta$ is used to seed the polymerization of soluble $\mathrm{A} \beta$, neuronal cell death develops that is directly proportional to the extent of polymerization. It is the process of $\mathrm{A} \beta$ polymerization, rather than any neurotoxic oligomeric species, that correlates with neuronal cell death. Using this two-component system (fibrillar $\mathrm{A} \beta$ and soluble $\mathrm{A} \beta$ ), we demonstrate precise control of both the initiation and termination of $\mathrm{A} \beta$-mediated neuronal cell death. We reveal that lot-to-lot variability of $\mathrm{A} \beta$ neurotoxicity is attributable to variable amounts of fibrillar $\mathrm{A} \beta$ and soluble $\mathrm{A} \beta$ found in biochemically identical lots of $\mathrm{A} \beta_{1-40}$. These studies demonstrate that neuronal cell death is mediated by nucleation-dependent amyloid polymerization. These findings reveal a novel conceptual framework for studying the structure-activity relationships of amyloidogenic peptides, allow for the precise control of cellular response to $A \beta$ and related peptides, and have implications for the therapeutic treatment of Alzheimer's disease and other amyloid disorders.

\section{Materials and Methods}

Atomic force microscopy. Samples of A $\beta$ solutions (100-200 $\mu \mathrm{l})$ were added to freshly cleaved mica and incubated for 5-10 min at room temperature. Samples were gently washed twice with $200 \mu \mathrm{l} /$ wash of filtered, deionized water. All images were generated by atomic force microscopy (AFM) (Molecular Imaging, Tempe, AZ) operated in Magnetic AC Mode. $\mathrm{A} \beta$ samples were imaged under filtered, deionized water using tips with a spring constant of $\sim 0.5 \mathrm{~N} / \mathrm{m}$, with a resonance frequency generally between 20 and $50 \mathrm{kHz}$ in water (depending on the particular tip or cantilever being used). An $18 \times 18 \mu \mathrm{m}$ area was typically scanned at three to five lines per second using $512 \times 512$ data points per line sampling. Images were collected using both height and deflection mode.

Transmission electron microscopy. Samples $(10 \mu \mathrm{l})$ of A $\beta$ solutions were adsorbed to 400 mesh Formvar carbon-coated copper grids (FCF400$\mathrm{Cu}$; Electron Microscopy Sciences, Fort Washington, PA). A $\beta$ samples were left on for $1 \mathrm{~min}$ and then negatively stained for 1 min with $1 \%$ ammonium molybdate. The stain was wicked off, and the grids were air dried. Grids were examined on a Philips (Aachen, Germany) 400 electron microscope located at the University of California, San Francisco Electron Microscopy Facility in the Department of Biochemistry and Biophysics.

Freshly solubilized $A \beta . \mathrm{A} \beta_{1-40}$ lyophilized powder (catalog \#641-10, lots MF-0641, MF-1041, MF-1141, and ME-0541; California Peptide Research, Napa, CA) was dissolved to $1 \mathrm{~mm}$ (1 mg of dry powder per 175 $\mu l$ of water based on quantitative amino acid analysis) using glass vials, incubated at room temperature for $3 \mathrm{~min}$, aliquoted into glass vials, and snap frozen on ethanol and dry ice.

Fibrillar $A \beta$ or "seed" preparation. A $\beta_{1-40}$ lyophilized powder (catalog \#641-10, lots MF-0641, MF-1041, MF-1141, and ME-0541; California Peptide Research) was dissolved to $1 \mathrm{~mm}$ ( $1 \mathrm{mg}$ of dry powder per $175 \mu \mathrm{l}$ of water) using glass vials, aged for $3 \mathrm{~d}$ at $37^{\circ} \mathrm{C}$, aliquoted into glass vials, and snap frozen on ethanol and dry ice. At least $90 \%$ of the total peptide present in these preparations was in the aggregated form, based on the observation that $>90 \%$ of peptide was removed by a $100,000 \times g$ spin (data not shown). Based on the morphology of aggregated $\mathrm{A} \beta$, as determined using transmission electron microscopy (TEM) (see Fig. 1), aggregated $\mathrm{A} \beta$ is referred to as fibrillar $\mathrm{A} \beta$ in this paper. These fibrillar $\mathrm{A} \beta$ preparations are also likely to contain $\mathrm{A} \beta$ protofibrils, as described previously (Harper and Lansbury, 1997; Walsh et al., 1999). The relative proportions of soluble and fibrillar $A \beta$ in different peptide preparations and treatments were determined by measuring the protein concentration of $\mathrm{A} \beta$ after centrifugation (using $\mathrm{A} \beta_{1-40}$ as a standard) and by measuring the characteristic $120 \mathrm{~nm}$ red shift of the excitation spectrum of the benzothiazole dye thioflavin-T (ThT) that occurs after ThT binding to fibrillar $\mathrm{A} \beta$ (LeVine, 1997).

Soluble $A \beta$ preparation. Disaggregated $\mathrm{A} \beta_{1-40}$ (catalog \#641-10, lots MF-0641, MF-1041, MF-1141, and ME-0541; California Peptide Research) was prepared by dissolving lyophilized powder to $7.5 \mathrm{~mm}$ in dimethylsulfoxide (DMSO) (23.3 $\mu$ l of DMSO per $1 \mathrm{mg}$ of dry powder) using glass vials and sonicating for $30 \mathrm{~min}$ in a bath sonicator. After dilution in basal media, DMSO-disaggregated $A \beta$ shows no fibrillar or other large aggregates when examined by AFM (see Fig. 1). Based on previous findings that DMSO dissolution of $\mathrm{A} \beta$ produces monomeric solutions containing variable amounts of $\mathrm{A} \beta$ dimers or other small oligomers (Garzon-Rodriguez et al., 1997; Harper et al., 1999; Tseng et al., 1999), DMSO-disaggregated $A \beta$ is referred to as soluble $A \beta$ in this paper. Stock solutions of soluble $\mathrm{A} \beta$ were snap frozen in small aliquots using glass vials and stored frozen at $-30^{\circ} \mathrm{C}$.

$I^{125}-A \beta$ preparation. $\mathrm{I}^{125}-\mathrm{A} \beta_{1-40}[2000 \mathrm{Ci} / \mathrm{mmol}$, with lactose, no BSA present; catalog \#IM294-25UCi (special order from Amersham Biosciences, Arlington Heights, IL)] was dissolved in DMSO at $100 \mu \mathrm{Ci} / \mathrm{ml}$, transferred to polypropylene tubes, and sonicated in a water-bath sonicator for $30 \mathrm{~min}$. Aliquots of $A \beta$ were snap frozen.

Unsheared and sheared $A \beta$ preparation. $\mathrm{A} \beta_{1-40}$ lyophilized powder (catalog \#641-10, lot MF-1141; California Peptide Research) was dissolved to $1 \mathrm{~mm}$ ( $1 \mathrm{mg}$ of dry powder per $175 \mu \mathrm{l}$ of water) and snap frozen on ethanol and dry ice. A frozen $1 \mathrm{~mm}$ stock was diluted to $30 \mu \mathrm{M}$ in 10 mм 2-(N-cyclohexylamino)ethanesulfonic acid, $\mathrm{pH} 9.0$, and $150 \mathrm{~mm}$ $\mathrm{NaCl}$ in a final volume of $1 \mathrm{ml}$. The $30 \mu \mathrm{m}$ stock was incubated for $2 \mathrm{~h}$ in a $37^{\circ} \mathrm{C}$ circulating water bath to allow for fibril growth; this solution was "unsheared fibrils." Sheared fibrils were produced by passing the solution 20 times through a 27 gauge needle. Shearing increased ThT signal $\sim 2.5$-fold. By both ThT signal and filtration, $\sim 50 \%$ of total peptide was in the fibrillar form (data not shown).

Tissue culture. Human cortical cultures were established using dissociated human cerebral tissue at 13-16 weeks gestation. Cortical tissue was provide by Advanced Bioscience Resources (Alameda, CA), and the protocol for obtaining fetal brain tissue complied with federal guidelines for fetal research and with the Uniformed Anatomical Gift Act. Cortical tissue was washed twice in $\mathrm{Ca}^{2+} / \mathrm{Mg}^{2+}$-free HBSS (H-9394; Sigma, St. Louis, $\mathrm{MO}$ ) and then dissociated by repeated pipetting in $10 \mathrm{ml}$ of cold HBSS with $1 \mathrm{ml}$ of DNase (D-4513; Sigma), and the solution was passed through a $100 \mu \mathrm{m}$ nylon cell strainer (21008-950; VWR Scientific, West Chester, PA). The cells obtained were then centrifuged for 5 min at $200 \times$ $g$, resuspended in a trypsin/EDTA solution $(0.05 \%$ trypsin and $0.53 \mathrm{~mm}$ EDTA in HBSS; T-3924; Sigma), and incubated for $20 \mathrm{~min}$ at $37^{\circ} \mathrm{C}$. After centrifugation, cells were resuspended in neuronal medium [MEM supplemented with B27 (17504-044; Invitrogen, Gaithersburg, MD), 1\% glucose, $1 \mathrm{~mm}$ sodium pyruvate, and $1 \mathrm{~mm}$ glutamine] and plated onto polyethyleneimine-coated 96 -well plates at a density of 125,000 cells per well. Cultures were maintained for 3 weeks before use, and culture media was replaced twice per week. By immunostaining, the cultures are $>90 \%$ neurons (positive for neurofilament or microtubule-associated protein2 ). The contaminating cells are glial fibrillary acidic protein positive (astrocytes) and complement receptor 3 (MAC-1) positive (microglia) (data not shown). These cells are likely present at the time of plating but do not appear to divide while in the defined medium.

Neuronal viability measurements. Neuronal viability was determined using several techniques: (1) cellular metabolic activity [determined using alamarBlue sodium 3'-[L-phenylaminocarbonyl-3,4-tetrazolium]bis (4-methoxy-6-nitro) benzene sulfonic acid hydrate (XTT), and 3-(4,5-dimethylthiazol-2-yl)-2,5-diphenyltetrazolium bromide (MTT)]; (2) membrane integrity [determined (a) by measuring the release of cytosolic enzyme lactate dehydrogenase (LDH) into the culture supernatant and (b) by staining with a membrane-permeable dye (Syto-13; S-7575; Molecular Probes, Eugene, OR) and a membrane-impermeable dye (propidium iodide; 1-348-639; Boehringer Mannheim, Indianapolis, IN)]; and (3) neuronal morphology (determined using phase contrast microscopy). Neuronal viability as determined using alamarBlue (catalog \#DAL1100; Biosource, Camarillo, CA), XTT (catalog \#1465015; Roche, Indianapolis IN), and LDH release were performed as described previously (Estus et al., 1997). Syto-13 and propidium iodide were used according to the instructions of the manufacturer. The MTT assay was obtained from Sigma (catalog \#TOX-1) and was used per the instructions of the manufacturer.

$A \beta_{1-42}$, human amylin, and the non-A $\beta$ component of Alzheimer's disease amyloid plaques preparation. Seed or aggregated preparations of 

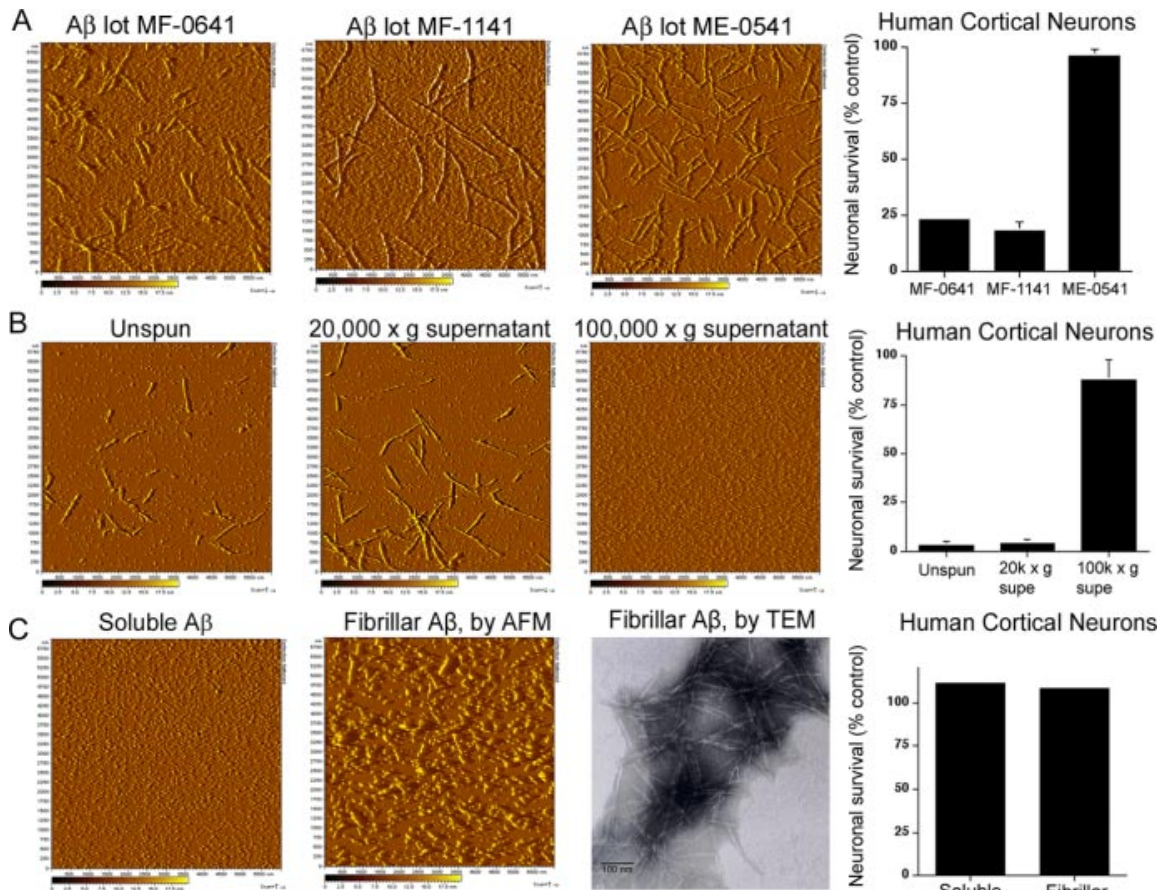

Fibrillar $A B$, by AFM
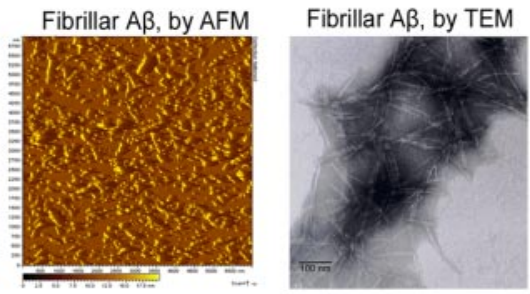

Human Cortical Neurons

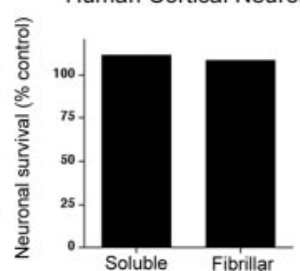

Figure 1. The presence of fibrillar $A \beta$ is essential, but not sufficient, for $A \beta$-mediated neuronal cell death. $A$, Synthetic lots of $A \beta_{1-40}$ (MF-0641, MF-1141, and ME-0541) were dissolved to a nominal $1 \mathrm{~mm}$ in water. They were then diluted to $30 \mu \mathrm{m}$ in basal media (MEM) and either imaged by AFM or added at $100 \mu \mathrm{l} /$ well $(n=3)$ to freshly aspirated human cortical neurons. Neuronal survival was determined using alamarBlue after $3 \mathrm{~d}$ of treatment. Note that lot ME-0541 has a significant number of fibrils present but was not toxic to the cells. $B$, Stocks (1 mm) of $A \beta_{1-40}$ (lot MF-0641) were diluted to $30 \mu \mathrm{m}$ in basal media and spun at room temperature for 20 min at $20,000 \times g$ or for $1 \mathrm{~h}$ at $100,000 \times g$. The unspun sample was kept at room temperature for $1 \mathrm{~h}$. Aliquots were imaged by AFM or added to primary human cortical neuron cultures. Neurons were incubated for $3 \mathrm{~d}$ at $37^{\circ} \mathrm{C}$ and then assayed for neuronal viability using alamarBlue. All treatments were in triplicate wells. Error bars indicate \pm SD. supe, Supernatant. $C$, DMSO stock (7.5 mm) of $A \beta_{1-40}$ (soluble $A \beta$ ) and 3 d aged $1 \mathrm{~mm}$ water stock (fibrillar $A \beta$ ), both lot MF-0641, were diluted to 30 $\mu \mathrm{M}$ in basal media (MEM) and either imaged by AFM or TEM or added at $100 \mu \mathrm{l} /$ well to primary human cortical neurons. All AFM images shown are deflection mode. Neuronal survival was determined using alamarBlue after $2 \mathrm{~d}$ of continuous treatment with either soluble $A \beta$ or fibrillar $A \beta$. In additional experiments, continuous treatment with fibrillar $A \beta$ for up to $7 \mathrm{~d}$ also did not affect neuronal survival (data not shown). Note that the $3 \mathrm{~d}$ aged stock was difficult to image by AFM. Some fields would not produce clean images, perhaps attributable to an excessive amount of aggregated material in those fields. Furthermore, large aggregates that were visible by inspection of the mica plate after adsorption were lost after washing of the AFM samples. The TEM image (in which excess liquid is wicked off) is likely to be more representative of the aggregate state of the samples compared with the AFM images (in which the sample is washed with water).

$\mathrm{A} \beta_{1-42}$, human amylin, and the non- $\mathrm{A} \beta$ component of Alzheimer's disease amyloid plaques (NAC) were made by dissolving lyophilized powder at $250 \mu \mathrm{M}$ in PBS (A $\left.\beta_{1-42}\right), 1 \mathrm{~mm}$ in $\mathrm{H}_{2} 0$ (human amylin), or $1.3 \mathrm{~mm}$ in $\mathrm{H}_{2} \mathrm{O}$ (NAC) and aging for $3 \mathrm{~d}$ at $37^{\circ} \mathrm{C}$. (All three peptides were synthesized by California Peptide Research: A $\beta_{1-42}$, catalog \#641-15, lot MF0639; human amylin, catalog \#641-50, lot NG-0213; and NAC, catalog \#641-80, lot ME-1125.) All seed preparations were aliquoted and frozen. Because $A \beta_{1-42}$ is not readily soluble in PBS, the cloudy suspension that resulted from adding $\mathrm{PBS}$ to $\mathrm{A} \beta_{1-42}$ was aged and then sonicated for 30 min before aliquoting and freezing. Soluble fractions were made by dissolving lyophilized powder in DMSO at $5 \mathrm{~mm}$, sonicating for $30 \mathrm{~min}$, and snap freezing aliquots. $\mathrm{A} \beta_{1-42}$ and human amylin solutions were diluted to $20 \mu \mathrm{M}$ in media and then filtered through $30 \mathrm{kDa}$ cutoff filters before treatment (filters were rinsed in $70 \% \mathrm{EtOH}$ in $\mathrm{H}_{2} \mathrm{O}$, aspirated, and dried before use; centriprep \#4306; Amicon, Beverly, MA).

\section{Results}

Structural requirements for $\mathbf{A} \boldsymbol{\beta}$-mediated neuronal cell death To understand the morphological features required for $A \beta$ mediated neurotoxicity, we used AFM to identify the aggregate forms of $A \beta$ present in three different lots of $A \beta_{1-40}$ that varied significantly in their neurotoxic properties when freshly solubilized at $1 \mathrm{~mm}$ in water and diluted to $30 \mu \mathrm{M}$ in tissue culture medium (Fig. 1A). Although all three freshly solubilized peptide lots contained fibrillar $\mathrm{A} \beta$ of comparable morphology, only lots MF-0641 and MF-1141 were neurotoxic to primary human cortical neurons. Lot ME-0541, which clearly contained fibrillar $\mathrm{A} \beta$ of comparable size and morphology as lots MF-0641 and MF1141, was not neurotoxic when freshly solubilized and added to primary human cortical neurons. Lot ME-0541 had a ThT signal that was fivefold higher than that of either lot MF-0641 or lot MF-1141, indicating that lot ME-0541 contained a greater proportion of aggregated or fibrillar $A \beta$ (data not shown.) These studies demonstrate that, although fibrillar $A \beta$ was present in neurotoxic lots of $A \beta$, it was not sufficient to generate neuronal cell death.

To determine whether the presence of fibrillar $\mathrm{A} \beta$ was required for mediating neuronal cell death, neurotoxic lot MF0641 was freshly solubilized at $1 \mathrm{~mm}$ in water, diluted to $30 \mu \mathrm{M}$ in tissue culture medium, and then centrifuged at $20,000 \times g$ for $20 \mathrm{~min}$ or $100,000 \times g$ for $60 \mathrm{~min}$ before addition of the supernatant to neuronal cultures. Centrifugation at $20,000 \times g$ did not remove the shorter $A \beta$ fibrils, nor did it diminish the neuronal cell death associated with lot MF-0641 (Fig. $1 B$ ). However, centrifugation at $100,000 \times g$ removed all fibrillar $\mathrm{A} \beta$ and associated neuronal cell death. Although centrifugation at $100,000 \times g$ did remove fibrillar $\mathrm{A} \beta$ as measured by AFM (Fig. $1 B$ ), it did not have a measurable affect on the protein concentration of lot MF-0641 before or after centrifugation (data not shown). These findings suggest that neurotoxic lot MF-0641 contained very small quantities of fibrillar $A \beta$. In fact, the ThT signal of neurotoxic lot MF-0641 shown in Figure $1 A$ was comparable with the ThT signal obtained with DMSO-disaggregated lot MF-0641 shown in Figure $1 C$. In contrast, the ThT signal of neurotoxic lot MF-0641 increased 20 -fold after aging for $3 \mathrm{~d}$ at $37^{\circ} \mathrm{C}$ (Fig. $1 \mathrm{C}$ and data not shown). This study clearly demonstrates that small quantities of fibrillar $\mathrm{A} \beta$ are essential, but not sufficient, for $\mathrm{A} \beta$-mediated neuronal cell death.

Similar results were obtained when neurotoxic lot MF-0641 was prepared as a DMSO stock solution before dilution into tissue culture medium. DMSO-solubilized lot MF-0641 did not contain fibrillar $\mathrm{A} \beta$ as demonstrated by AFM and was not toxic to cortical neurons (Fig. 1C). Based on the lack of fibrillar $\mathrm{A} \beta$ in DMSO-solubilized $\mathrm{A} \beta_{1-40}$ and a similar appearance of DMSOsolubilized $\mathrm{A} \beta$ to preparations after centrifugation at $100,000 \times g$ for $60 \mathrm{~min}$, we will operationally refer to these preparations as "soluble A $\beta$." Previous publications have demonstrated that similar preparations of $\mathrm{A} \beta_{1-40}$ contain monomer $\mathrm{A} \beta$ as well as $\mathrm{A} \beta$ dimers and other low $n$-mer aggregates (Garzon-Rodriguez et al., 1997; Harper et al., 1999; Tseng et al., 1999). In addition to the lack of neuronal cell death associated with the removal of fibrillar 
$\mathrm{A} \beta$ from peptide solutions, we found that neurotoxic activity was also abolished if peptide stocks were allowed to aggregate for extended periods of time (overaging). A $\beta$ lot MF-0641 was toxic when freshly prepared at $1 \mathrm{~mm}$ in water and then diluted into tissue culture medium (Fig. $1 A)$. However, its neurotoxic properties were abolished when $1 \mathrm{~mm}$ stocks were allowed to aggregate for an additional $3 \mathrm{~d}$ at $37^{\circ} \mathrm{C}$ (Fig. 1C). Thus, both centrifugation experiments and solubilization/aging experiments demonstrate the lack of neuronal cell death associated with soluble $\mathrm{A} \beta$ alone or fibrillar $\mathrm{A} \beta$ alone.

\section{Nucleation-dependent A $\beta$}

polymerization is an essential component of $\mathrm{A} \boldsymbol{\beta}$-mediated neuronal cell death

Previous studies using an all-D-enantiomer of $\mathrm{A} \beta$ suggested that the neurotoxic actions of $\mathrm{A} \beta$ are not attributable to a stereoisomer-specific ligand-receptor interaction but are more likely attributable to amyloid-mediated cellular interactions that are critically dependent on fibril formation (Cribbs et al., 1997). The lack of neuronal cell death found after neuronal cultures were treated with either fibrillar $\mathrm{A} \beta$ alone or soluble $\mathrm{A} \beta$ alone further indicated that $\mathrm{A} \beta$-mediated neuronal cell death might be a dynamic process associated with protein aggregation rather than a more conventional ligand-receptor interaction. Because $A \beta$ fibril elongation is a nucleation-dependent polymerization process, we sought to determine whether nucleation-dependent polymerization of $\mathrm{A} \beta$ fibrils along the neuronal plasma membrane would elicit $\mathrm{A} \beta$-mediated neurotoxicity. To direct $\mathrm{A} \beta$ polymerization to the neuronal cell surface, fibrillar $\mathrm{A} \beta_{1-40}$ was incubated in cultures of primary human cortical neurons for $1 \mathrm{~h}$, and then the culture wells were washed to remove unbound fibrils. Whereas treatment with $1 \mu \mathrm{M}$ fibrillar $\mathrm{A} \beta$ for up to $7 \mathrm{~d}$ was not toxic to human cortical neurons, the addition of $20 \mu \mathrm{M}$ soluble $\mathrm{A} \beta$ to cultures previously treated with fibrillar $\mathrm{A} \beta$ resulted in robust neuronal cell death after 2-3 d (Fig. 2). Interestingly, neuronal cultures pretreated for $1 \mathrm{~h}$ with fibrillar $A \beta$ and then maintained for $7 \mathrm{~d}$ in culture demonstrated robust neuronal cell death $2-3 \mathrm{~d}$ after the addition of soluble $\mathrm{A} \beta$, suggesting that fibrillar $\mathrm{A} \beta$ forms stable interactions with the neuronal cell membrane (data not shown). The fibrillar $\mathrm{A} \beta$ used in these studies were prepared from solutions containing highly aggregated, short, bundled fibrils, as determined by TEM (Fig. $1 C$ ). Similar results have been obtained using fibrillar $\mathrm{A} \beta$ and soluble $\mathrm{A} \beta$ prepared from a number of different lots of $A \beta_{1-40}$. In addition, we found that freshly solubilized lots of $\mathrm{A} \beta_{1-40}$ that contain fibrils, as determined by AFM, can also be used as a source of fibrillar $\mathrm{A} \beta$ (data not shown). Although we have not extensively characterized the biochemical properties of the fibrillar $\mathrm{A} \beta$ used in these studies, its appearance by AFM and TEM (fibril lengths $>1 \mu \mathrm{m}$ and height/
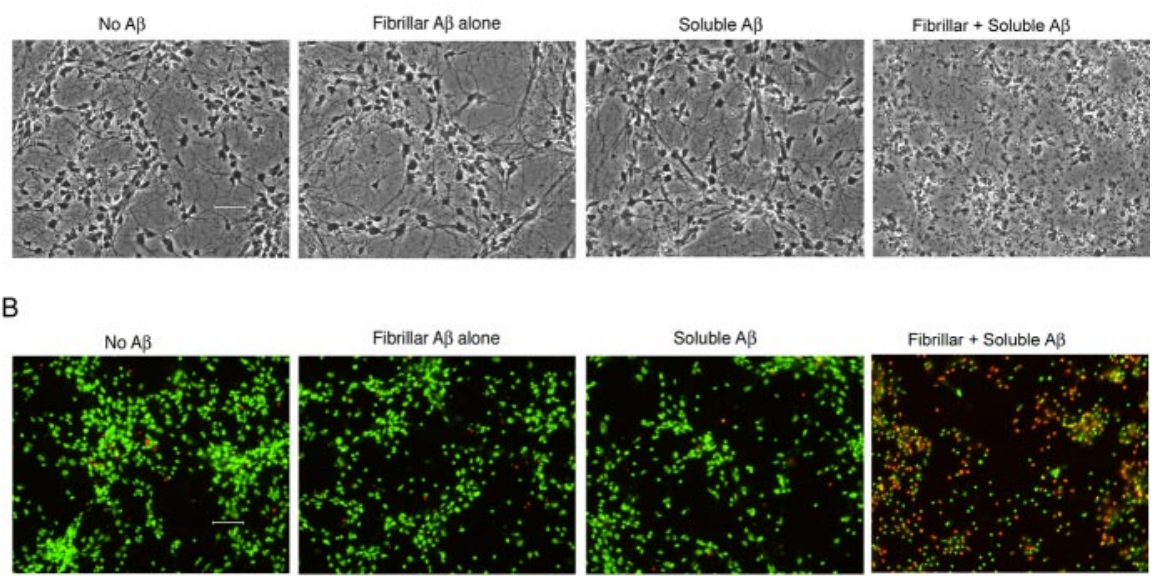

Fibrillar + Soluble $A \beta$
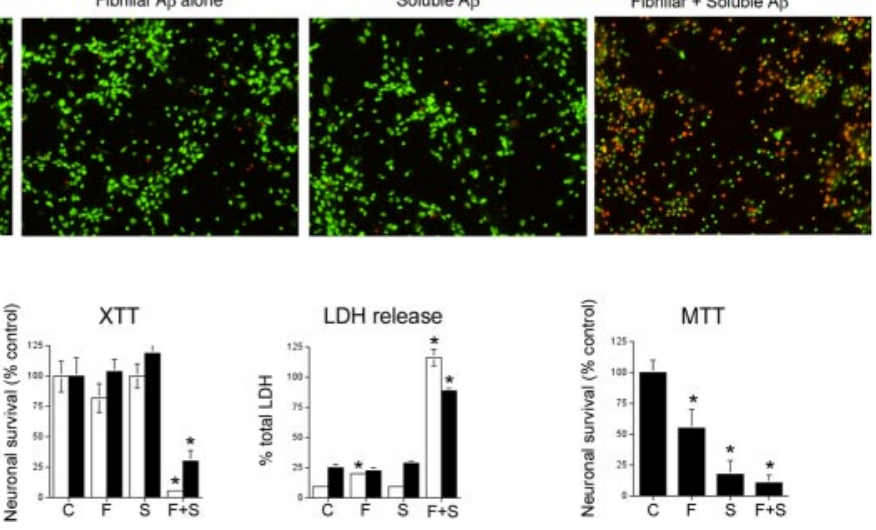

Figure 2. The presence of both soluble $A \beta$ and fibrillar $A \beta$ are required for $A \beta$-mediated neuronal cell death. Cultures of human cortical neurons were treated with media alone or media containing $1 \mu \mathrm{m}$ fibrillar $A \beta$. After $1 \mathrm{~h}$, culture medium was aspirated and replaced with media alone or media containing $20 \mu \mathrm{m}$ soluble $A \beta$. In total, four treatment conditions were used in

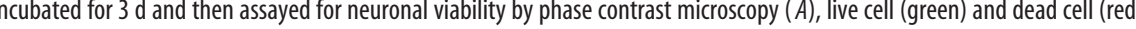
studies using fibrillar $A \beta$. Error bars indicate $\pm S D .{ }^{*} p<0.001$ versus control cultures. Statistical analysis was based on the

width of 7-10 nm) is similar to the structural properties reported previously for A $\beta$ fibrils (Walsh et al., 1997).

The neuronal cell death associated with nucleationdependent $\mathrm{A} \beta$ polymerization was confirmed using methods that assess both the metabolic integrity of the neuronal cultures and the presence of an intact cell surface membrane (Fig. 2). Treatment with both fibrillar $\mathrm{A} \beta$ and soluble $\mathrm{A} \beta$ was required to demonstrate significant effects on neuronal viability as assessed by cell morphology (Fig. $2 \mathrm{~A}$ ), disruption of plasma membrane as determined by live/dead cell staining (Fig. $2 B$ ) and the release of the cytoplasmic enzyme LDH (Fig. 2C), and loss of mitochondrial potential as measured by two different redox dyes, XTT and alamarBlue (Fig. $2 C$ ). In addition to measuring overt neuronal cell death after treatment with fibrillar $\mathrm{A} \beta$ and/or soluble $\mathrm{A} \beta$, biochemical responses associated with $\mathrm{A} \beta$-mediated neuronal cell death were also evaluated using this two-component experimental paradigm. In particular, activation and phosphorylation of Jun kinase and c-Jun, critical components of the cellular signaling pathway mediating $\mathrm{A} \beta$ neurotoxicity (Bozyczko-Coyne et al., 2001; Morishima et al., 2001; Troy et al., 2001), were also found to require treatment with both fibrillar $\mathrm{A} \beta$ and soluble $\mathrm{A} \beta$ (data not shown), indicating that activation of this cell death signaling pathway was tightly coupled to nucleation-dependent 
$\mathrm{A} \beta$ polymerization. Therefore, a variety of independent measurements of neuronal viability clearly demonstrated that ongoing $\mathrm{A} \beta$ polymerization appeared to be an essential component of $\mathrm{A} \beta$-mediated neuronal cell death.

\section{The reduction of the cellular MTT to MTT formazan is not a reliable early indicator of $\mathrm{A} \beta$-mediated neuronal cell death} Tetrazolium salts, such as MTT, are routinely used as colorimetric agents for measuring cell viability in cytotoxicity assays (Hansen et al., 1989). Cellular metabolic activity, or more precisely cellular redox activity, results in the reduction of soluble MTT to the insoluble MTT formazan. The MTT assay has been extensively used in studies addressing the neurotoxic properties of $A \beta$. However, it is likely that use of the MTT assay in A $\beta$ neuronal cell death studies has confounded the interpretation of experiments using various aggregate forms of $A \beta$. It has been reported by several laboratories that treatment with $\mathrm{A} \beta$ can lead to a decrease in MTT formazan production in the absence of overt cell death (Shearman et al., 1994; Hertel et al., 1996; Liu et al., 1997; Soriano et al., 2003). A number of different explanations have been proposed for this observation, including $\mathrm{A} \beta$ effects on membrane properties, MTT formazan exocytosis, and unknown intracellular targets whose interaction with $\mathrm{A} \beta$ is mediated by endosomal/ lysosomal acidification (Hertel et al., 1996; Liu et al., 1997; Kane et al., 1999). Although the mechanisms by which $\mathrm{A} \beta$ can reduce insoluble MTT formazan formation in the absence of overt cell death are in dispute, the MTT formazan assay has been reported to be a specific early indicator of $\mathrm{A} \beta$-mediated cell death (Shearman et al., 1994).

We and others have found that amyloidogenic proteins such as $\mathrm{A} \beta$ uniquely alter cellular MTT formazan crystal formation such that needle-shaped MTT formazan crystals are formed that puncture the cell plasma membrane (Shearman et al., 1995; Hertel et al., 1996) (data not shown). As reported previously (Shearman et al., 1995; Hertel et al., 1996), this effect of $A \beta$ on MTT formazan crystal formation is not shared with other structurally related tetrazolium redox dyes. Overall, these findings suggest that the MTT assay might not be a reliable indicator of overt $\mathrm{A} \beta$-mediated neuronal cell death.

To directly test the reliability of the insoluble MTT formazan assay as an early indicator of $\mathrm{A} \beta$-mediated neuronal cell death, we treated sister neuronal cultures with fibrillar $\mathrm{A} \beta$ alone, soluble $\mathrm{A} \beta$ alone, or both fibrillar $\mathrm{A} \beta$ and soluble $\mathrm{A} \beta$ and compared the neuronal viability determined using the MTT assay with that obtained by measurement of plasma membrane integrity using LDH release and cellular redox activity using two different soluble redox dyes, XTT and alamarBlue. As shown by the black bars in Figure $2 C$, treatment of primary human cortical neurons with either fibrillar $\mathrm{A} \beta$ alone or soluble $\mathrm{A} \beta$ alone had no effect on $\mathrm{LDH}$ release or cellular redox activity when assayed using soluble redox dyes. In contrast, treatment with either fibrillar $A \beta$ alone or soluble $\mathrm{A} \beta$ alone had a significant affect on neuronal viability only when cellular redox activity was determined using the insoluble MTT formazan assay. We repeated these studies a number of times using primary mouse, rat, and human cortical neurons and have consistently found the MTT formazan assay to indicate A $\beta$ neurotoxicity under conditions in which there is no detectable $\mathrm{A} \beta$ effect on neuronal viability as determined by phase contrast microscopy, live/dead cell staining, LDH release, and soluble redox dyes (data not shown). Because A $\beta$-mediated neuronal cell death, as determined using a variety of methods other than the insoluble MTT formazan assay, requires treatment with both soluble $A \beta$ and fibrillar $A \beta$, the reduction of insoluble MTT
A $\quad-125 A \beta$ incorporation

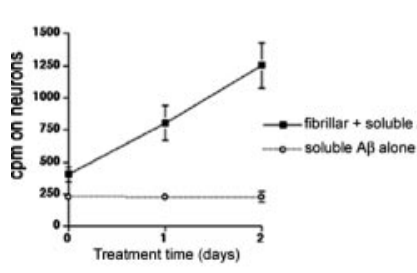

Figure 3. Soluble $A \beta$ incorporates onto $A \beta$ seeded neurons. $A$, Human neurons were treated with $1 \mu \mathrm{m}$ fibrillar $A \beta$ or vehicle for $1 \mathrm{~h}$, followed by aspiration. A solution of $20 \mu \mathrm{m}$ soluble $A \beta$ containing ${ }^{125} \mathrm{I}-\mathrm{A} \beta_{1-40}(20,000 \mathrm{cpm} / 100 \mu \mathrm{l})$ was then added to the cultures. At various time points, cells were washed twice with PBS and solubilized for gamma counting. Solubilization was done by adding $150 \mu \mathrm{l} /$ well Solvable (catalog \#6NE9100; Packard, Meridian, (T), mixing, and transferring to a tube. Radioactivity from these samples was then measured on a gamma counter. Wells were then washed twice with PBS at $150 \mu \mathrm{l} /$ wash. These washes were also collected and gamma counted. Counts from the two final washes were added to counts from Solvable-harvested wells to get total counts incorporated on cells. B, Sister neuronal cultures were assayed for viability using alamarBlue. All treatments were in triplicate wells. Error bars indicate $\pm S D$.

formazan found after treatment with either soluble $A \beta$ alone or fibrillar $\mathrm{A} \beta$ alone cannot be interpreted as an early indicator of neuronal cell death.

Our observation that treatment of human cortical neurons with soluble $\mathrm{A} \beta$ can lead to a reduction in MTT formazan formation in the absence of overt neuronal cell death is contrary to previous studies that did not show an effect of soluble $A \beta$ on MTT formazan formation using cultured rat primary cortical neurons (Walsh et al., 1999) or rat primary hippocampal neurons (Ward et al., 2000). However, these previous studies only evaluated the effects of soluble A $\beta$ on MTT formazan formation after relatively short treatment periods $(0.5-2 \mathrm{~h})$, whereas the studies reported here used treatment periods of $2-3 \mathrm{~d}$. The results presented here demonstrate that, with longer incubation time, soluble $\mathrm{A} \beta$ can lead to a reduction in the MTT assay in the absence of overt neuronal cell death.

Based on these and previous findings (Patel et al., 1996; Liu et al., 1997; Soriano et al., 2003), the studies reported here strongly indicate that the MTT formazan assay is an unreliable indicator of $A \beta$-mediated neuronal cell death. Furthermore, these findings suggest that previous results on the neurotoxic properties of $A \beta$ fibrils, protofibrils, or other oligomeric species should be interpreted with caution if neuronal cell death was inferred using the MTT formazan assay.

\section{The extent and rate of neuronal cell death can be precisely controlled by conditions that alter the rate of nucleation- dependent $\mathrm{A} \boldsymbol{\beta}$ polymerization}

To further characterize the role of nucleation-dependent polymerization in $A \beta$-mediated neurotoxicity, we evaluated the effect of fibrillar $A \beta$ pretreatment on the interaction of soluble $A \beta$ with primary human cortical neurons. Using trace amounts of soluble ${ }^{125} \mathrm{I}-\mathrm{A} \beta_{1-40}$, we found that pretreatment of cultured cortical neurons with fibrillar $A \beta$ dramatically enhanced the incorporation of soluble $\mathrm{A} \beta$ onto the neuronal monolayer (Fig. $3 A$ ). Under the conditions used ( $1 \mu \mathrm{m}$ fibrillar $\mathrm{A} \beta$ and $20 \mu \mathrm{m}$ soluble $\mathrm{A} \beta$ ), the incorporation of soluble $A \beta$ was linear over $2 \mathrm{~d}$ of treatment. Overt neuronal cell death was only associated with the incorporation of soluble $A \beta$ along the neuronal cell surface (Fig. $3 B$ ), further suggesting that ongoing fibril polymerization might be critical for mediating $\mathrm{A} \beta$ neurotoxicity.

If nucleation-dependent amyloid polymerization is a critical component of $\mathrm{A} \beta$-mediated neurotoxicity, then conditions that 


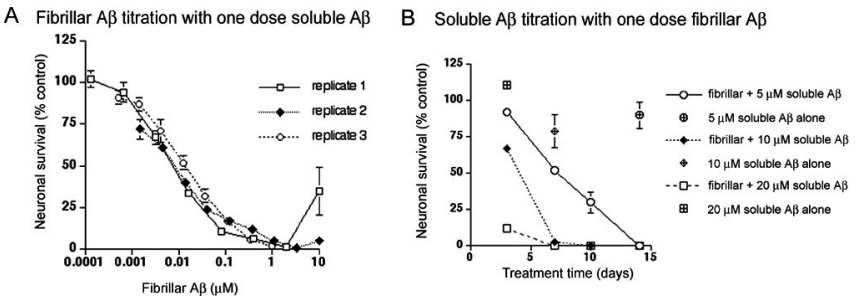

Figure 4. The extent of $A \beta$-mediated neuronal cell death is dependent on both fibrillar $A \beta$ concentration and on soluble $A \beta$ concentration. $A$, Human cortical neurons were pretreated for $1 \mathrm{~h}$ with the indicated concentrations of fibrillar $A \beta$. Nonadhering fibrillar $A \beta$ was removed by aspiration, and $20 \mu \mathrm{m}$ soluble $A \beta$ was added to the cultures. Neuronal cultures were incubated for $3 \mathrm{~d}$ and then assayed for viability using alamarBlue. Three independent neuronal culture preparations were assayed on different days using frozen aliquots of the same fibrillar $A \beta$ preparation. We presume that the variability seen at the highest concentration of fibrillar $A \beta$ is attributable to variations in the amount of fibrillar $A \beta$ left behind after aspiration of the fibrillar $A \beta$ pretreatment. Sufficiently high concentrations of fibrillar $A \beta$ can inhibit toxicity, as seen in Figure 6 , and this variability was eliminated when the fibrillar $A \beta$ pretreatment was washed with media alone before adding soluble $A \beta$ (data not shown). $B$, Human cortical neurons were pretreated for $1 \mathrm{~h}$ with $1 \mu \mathrm{m}$ fibrillar $A \beta$. Pretreatment was aspirated, and $5 \mu \mathrm{m}$ (circles), $10 \mu \mathrm{m}$ (diamonds), or $20 \mu \mathrm{m}$ (squares) soluble $A \beta$ was added to the cultures. Neuronal viability was determined by alamarBlue after $3,7,10$, and $14 \mathrm{~d}$ of treatment. All treatments were in triplicate wells. Error bars indicate \pm SD.

enhance or diminish the rate of $\mathrm{A} \beta$ polymerization should have similar effects on the rate and extent of $\mathrm{A} \beta$-mediated neuronal cell death. Because the rate of nucleation-dependent polymerization is proportional to both seed concentration and monomer concentration, we evaluated the effects of fibrillar $A \beta$ concentration and soluble $\mathrm{A} \beta$ concentration on $\mathrm{A} \beta$-mediated neuronal cell death. Human cortical neurons were pretreated with various concentrations of fibrillar $A \beta$ for $1 \mathrm{~h}$, the culture medium was aspirated, and the neurons were then maintained for $3 \mathrm{~d}$ in the presence of $20 \mu \mathrm{M}$ soluble $\mathrm{A} \beta$. As expected, increasing concentrations of fibrillar $\mathrm{A} \beta$ from $0.1 \mathrm{nM}$ to $1 \mu \mathrm{M}$ dramatically enhanced the extent of $\mathrm{A} \beta$-mediated neuronal cell death (Fig. $4 A$ ). Similar results were obtained when fibrillar $A \beta$ concentration was kept constant and soluble $\mathrm{A} \beta$ concentration was varied from 5 to $20 \mu \mathrm{M}$. As shown in Figure $4 B$, increasing the concentration of soluble $A \beta$ enhanced both the rate and extent of $A \beta$-mediated neuronal cell death after $3,7,10$, and $14 \mathrm{~d}$ of treatment. These studies clearly demonstrate a close relationship between the rate of $\mathrm{A} \beta$ polymerization and both the rate and extent of $\mathrm{A} \beta$ mediated neuronal cell death.

Studies on nucleation-dependent protein polymerization have demonstrated that the rate of polymerization is dependent on both the concentration of fibril seeds and the number of free fibril ends (Harper and Lansbury, 1997). Specifically, conditions that enhance the number of free fibril ends will enhance the rate of protein polymerization, even if the concentrations of fibrils and monomers are kept constant. Based on this relationship, we would expect treatments that increase the number of free $A \beta$ fibril ends, without changing the concentrations of fibrillar or soluble $\mathrm{A} \beta$, would also enhance the rate of $\mathrm{A} \beta$-mediated neuronal cell death. To address this relationship experimentally, we sheared $A \beta$ fibrils by repeated passage through a 27 gauge needle. Using AFM (Fig. 5A,B) and TEM (data not shown), we found that the sheared fibrils were significantly shorter than unsheared $\mathrm{A} \beta$ fibrils. Pretreatment with sheared $\mathrm{A} \beta$ fibrils, followed by treatment with soluble $A \beta$, resulted in significantly greater neuronal cell death after $3 \mathrm{~d}$ of treatment compared with pretreatment with unsheared $A \beta$ fibrils. For example, similar effects on neuronal survival were found after $1 \mathrm{~h}$ pretreatment with either
$1.2 \mu \mathrm{M}$ unsheared $\mathrm{A} \beta$ fibrils or $0.3 \mu \mathrm{M}$ sheared $\mathrm{A} \beta$ fibrils, followed by $3 \mathrm{~d}$ of treatment with $20 \mu \mathrm{M}$ soluble $\mathrm{A} \beta$ (Fig. $5 C$ ). Neuronal cultures treated with unsheared or sheared $\mathrm{A} \beta$ fibrils alone did not exhibit cell death (data not shown), suggesting that both unsheared and sheared fibrils require soluble $\mathrm{A} \beta$ to mediate overt neuronal cell death. Thus, the neurotoxic potency of $\mathrm{A} \beta$ increases as the number of fibril ends increases, as would be expected for a nucleation-dependent polymerization process.

The neurotoxic dependency on both fibrillar $\mathrm{A} \beta$ concentration and soluble $A \beta$ concentration was reproduced using four different lots of $\mathrm{A} \beta_{1-40}$ peptide, demonstrating that these findings were not unique to individual lots of $A \beta$ peptide. However, the neurotoxic potency of fibrillar $A \beta$ did vary from lot to lot, suggesting that the number of free fibril ends was peptide lot and preparation dependent (data not shown). Nonetheless, the neurotoxic potency of individual preparations of fibrillar $\mathrm{A} \beta$ was highly reproducible, and frozen aliquots of fibrillar $\mathrm{A} \beta$ showed consistent neurotoxic activity across multiple experiments (Fig. $4 A$ ). These findings provide a highly reproducible method by which to control the rate of $\mathrm{A} \beta$-mediated neuronal cell death and associated signaling pathways and should allow a greater understanding of the molecular events associated with amyloidmediated pathology. Previous studies using human cerebrovascular smooth muscle cells have demonstrated that cell surface A $\beta$ fibril formation plays an important role in causing pathologic responses in this cell type (Van Nostrand et al., 1998). Confocal microscopy studies using anti-A $\beta$ and anti-neural cell adhesion molecule antibodies also indicates that $\mathrm{A} \beta$ polymerization is closely associated with the neuronal cell surface under conditions that promote overt neuronal cell death (data not shown). Together, these series of studies strongly suggest that the nucleationdependent polymerization of $\mathrm{A} \beta_{1-40}$, most likely along the neuronal cell surface, is an essential component of $\mathrm{A} \beta$-mediated neuronal cell death. However, our interpretation of these studies did not take into consideration the potential for stable soluble $\mathrm{A} \beta$ oligomers to be generated by the treatment conditions used in these studies. Such stable and toxic $\mathrm{A} \beta$ oligomers could be generated by the process of $\mathrm{A} \beta$ polymerization and then diffuse onto the neuronal cell surface. We therefore conducted a series of studies in which fibrillar $\mathrm{A} \beta$ and soluble $\mathrm{A} \beta$ were mixed in solution for various lengths of time before treatment of primary neuronal cultures to determine whether there was a soluble component of $\mathrm{A} \beta$-mediated neuronal cell death or whether $\mathrm{A} \beta$-mediated neuronal cell death was more tightly associated with $\mathrm{A} \beta$ polymerization and overt fibril formation. In particular, we reasoned that, if $\mathrm{A} \beta$ neuronal cell death was dependent on fibril elongation along the neuronal cell surface, then solutions of fibrillar $A \beta$ and soluble $\mathrm{A} \beta$ would be toxic to neurons only if the solution conditions maintained ongoing $\mathrm{A} \beta$ polymerization. However, if stable neurotoxic oligomers of $A \beta$ were generated in solution by the process of $\mathrm{A} \beta$ polymerization, then solutions of fibrillar $\mathrm{A} \beta$ and soluble $\mathrm{A} \beta$ would be toxic to neurons even if solution conditions did not maintain ongoing $A \beta$ polymerization. As shown in Figure $6 A$, solutions containing $25 \mu \mathrm{M}$ soluble $\mathrm{A} \beta$ and 62,125 , or $250 \mathrm{nM}$ fibrillar $\mathrm{A} \beta$ were preincubated up to $6 \mathrm{~h}$ at $37^{\circ} \mathrm{C}$ before addition to neuronal cultures. After $30 \mathrm{~min}$ of preincubation, all three fibril concentrations generated solutions with very similar neurotoxic potencies. The neuronal cell death found in these treatments was comparable with that obtained using freshly solubilized neurotoxic lots of $\mathrm{A} \beta$ (Fig. 1). The relatively small amount of fibrillar $\mathrm{A} \beta$ required to induce neuronal cell death is consistent with our observation that neurotoxic lots of $A \beta_{1-40}$ contain very small amounts of fibrillar $\mathrm{A} \beta$ ( $<5 \%$ of total peptide concentra- 

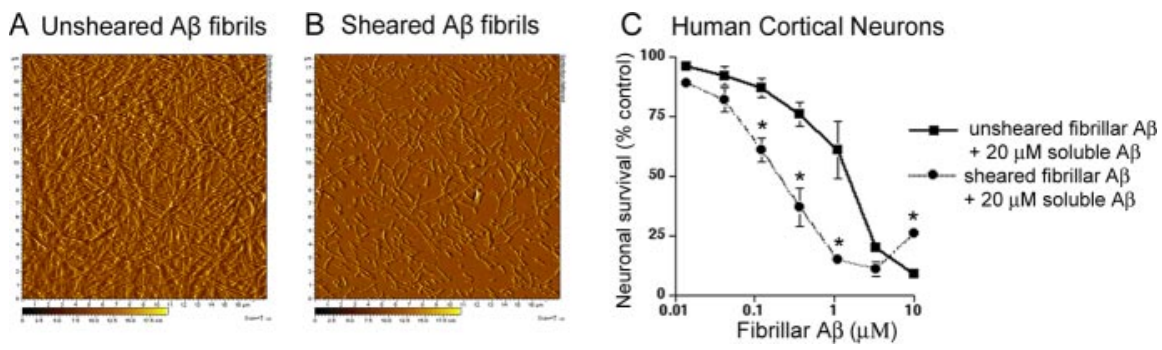

Figure 5. Increasing the number of fibril ends by shearing leads to increased potency of A $\beta$ fibril seeds. Deflection mode AFM images of unsheared $(A)$ and sheared $(B) A \beta$ fibrils generated at $\mathrm{pH} 9.0,150 \mathrm{~mm} \mathrm{NaCl}$. These conditions were found to produce long, nonlaterally associated fibrils as determined by AFM. Samples $(30 \mu \mathrm{m})$ were incubated for $\sim 5 \mathrm{~min}$ at room temperature on mica either immediately before (for unsheared samples) or immediately after (for sheared samples) shearing. The shorter, sheared fibrils do not stick well to mica at pH 9.0. NaCl was spiked in to a final concentration of $250 \mathrm{~mm}$ in the sheared fibrils immediately before adding to mica to enhance the adsorption of sheared fibrils to the mica surface. Although this treatment did enhance fibril adsorption, it is important to note that fibril adsorption to mica surface is not quantitative, and thus the apparent reduction in fibril content after shearing is likely attributable to differences in adsorption rather than loss of fibrils caused by shearing. Thioflavin- $T$ signal was increased 2.5-fold in sheared samples compared with the unsheared samples (data not shown). C, Human cortical neurons were treated with the indicated concentration of sheared and unsheared fibrils (at pH 9.0, $150 \mathrm{~mm} \mathrm{NaCl}$ ) for $1 \mathrm{~h}$. Dilutions were performed with $10 \mu \mathrm{m}$ soluble $A \beta$ present to ensure that the fibrils did not disaggregate by loss of monomer from fibril ends. Nonadhering $A \beta$ fibrils were removed by aspiration, and $20 \mu \mathrm{m}$ soluble $A \beta$ was added to the cultures. Cultures were maintained for $3 \mathrm{~d}$, and neuronal viability was determined by alamarBlue. Statistical analysis was based on the means $\pm S D(n=6)$. ${ }^{*} p=$ 0.005 versus cultures treated with unsheared $A \beta$ fibrils based on ANOVA, followed by Fisher's PLSD test using StatView software (version 5.0; SAS Institute). ANOVA indicated that there was a group effect of cultures treated with unsheared $A \beta$ fibrils versus cultures treated with sheared $A \beta$ fibrils ( $p=0.002)$, as well as an interaction effect between dose and treatment $(p<0.0001)$.
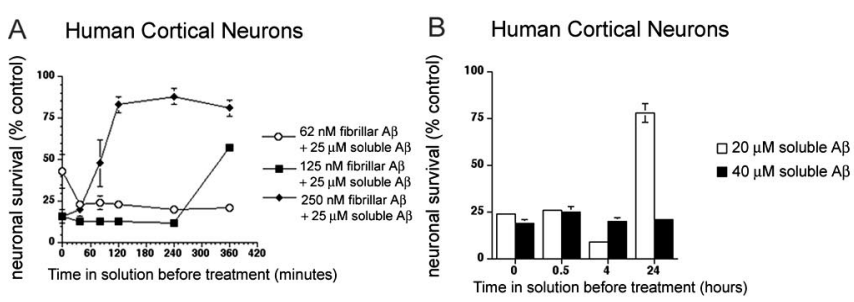

Figure 6. $\quad A \beta$-mediated neuronal cell death requires ongoing nucleation-dependent polymerization. $A$, Fibrillar $A \beta(62 \mathrm{~nm})$ (open circles), $125 \mathrm{~nm}$ fibrillar $A \beta$ (filled squares), or $250 \mathrm{~nm}$ fibrillar $A \beta$ (filled diamonds) was added to $25 \mu \mathrm{m}$ soluble $A \beta$ and left to incubate at $37^{\circ} \mathrm{C}$ for the indicated lengths of time before adding to primary human cortical neurons. Cells were treated for $3 \mathrm{~d}$, and then neuronal survival was determined by alamarBlue. Note that increasing concentrations of fibrillar $A \beta$ led to a loss of neuronal cell death, presumably because of depletion of soluble $A \beta . B$, Fibrillar $A \beta(62 \mathrm{~nm})$ was added to either 20 or $40 \mu$ m soluble $A \beta$ and left to age at $37^{\circ} \mathrm{C}$ for the indicated times before adding to primary human cortical neurons. Note that the loss of neuronal cell death found using $62 \mathrm{~nm}$ fibrillar $\mathrm{A} \beta$ at $24 \mathrm{~h}$ of aging is prevented by using a higher soluble $A \beta$ concentration. C, Human cortical neurons were pretreated with $1 \mu \mathrm{m}$ fibrillar $A \beta$ for $1 \mathrm{~h}$. Nonadhering fibrillar $A \beta$ was removed by aspiration, and cultures were treated with $20 \mu \mathrm{m}$ soluble $A \beta$ with or without $5 \mu \mathrm{m}$ fibrillar $A \beta$. Cultures were incubated for $3 \mathrm{~d}$, and then neuronal survival was determined by alamarBlue. The addition of $5 \mu \mathrm{m}$ fibrillar $A \beta$ significantly inhibited the neuronal cell death normally found using $20 \mu$ m soluble $A \beta$, presumably caused by depletion of soluble $A \beta$. All treatments were in triplicate wells. Error bars indicate \pm SD.

tion of neurotoxic lots MF-0641 and MF-1141 were in fibrillar form based on ThT and centrifugation experiments; data not shown). However, with longer preincubation times up to $6 \mathrm{~h}$, solutions containing the higher concentration of fibrillar $\mathrm{A} \beta$ showed dramatic loss of neurotoxic potency. One potential interpretation of these studies was that the solutions containing higher concentrations of fibrillar $\mathrm{A} \beta$ had consumed all of the soluble $\mathrm{A} \beta$ and could no longer maintain ongoing $A \beta$ polymerization when added to neuronal cultures. To directly address this possibility, we repeated these studies using $62 \mathrm{~nm}$ fibrillar $\mathrm{A} \beta$ and either 20 or $40 \mu \mathrm{M}$ soluble $\mathrm{A} \beta$. Whereas the solution containing $20 \mu \mathrm{M}$ soluble $A \beta$ lost its neurotoxic activity when preincubated for $24 \mathrm{~h}$, the solution containing $40 \mu \mathrm{M}$ soluble $\mathrm{A} \beta$ maintained its ability to cause neuronal cell death (Fig. $6 B$ ). Thus, increasing the soluble $\mathrm{A} \beta$ concentration directly extended the duration of neurotoxic activity associated with a fixed concentration of fibrillar A $\beta$. Conversely, as predicted for a nucleation-dependent polymerization process, the addition of fibrillar $\mathrm{A} \beta$ should inhibit neuronal cell death when amounts sufficient to consume all available soluble $\mathrm{A} \beta$ are added to neuronal cultures. Cortical cultures were pretreated for $1 \mathrm{~h}$ with 1 $\mu \mathrm{M}$ fibrillar $\mathrm{A} \beta$, washed, and then treated with $20 \mu \mathrm{M}$ soluble $\mathrm{A} \beta$, plus either 0 or 5 $\mu \mathrm{M}$ fibrillar $\mathrm{A} \beta$. After $3 \mathrm{~d}$ of treatment, neuronal viability was determined using the alamarBlue assay. As shown in Figure $6 C$, adding an additional $5 \mu \mathrm{M}$ fibrillar $\mathrm{A} \beta$ inhibited neuronal cell death by $85 \%$ compared with the cultures pretreated with $1 \mu \mathrm{M}$ fibrillar $\mathrm{A} \beta$ and $20 \mu \mathrm{M}$ soluble $\mathrm{A} \beta$ alone. Thus, through a variety of treatment conditions that altered the rate and extent of $\mathrm{A} \beta$ polymerization, we have been able to demonstrate a strong correlation of the rate and extent of $A \beta$ polymerization with the rate and extent of $\mathrm{A} \beta$ mediated neuronal cell death.

To further investigate the possibility that a stable, soluble species of $\mathrm{A} \beta$ could be mediating neurotoxicity under these conditions, we evaluated the conditioned media from neuronal cultures treated with fibrillar $\mathrm{A} \beta$ and soluble $\mathrm{A} \beta$. Cortical cultures were pretreated for $1 \mathrm{~h}$ with fibrillar $\mathrm{A} \beta$ and washed extensively, and then soluble $\mathrm{A} \beta$ was added to the cultures. After 1 , 2 , or $3 \mathrm{~d}$ of treatment, the conditioned media from these neuronal cultures was transferred to cortical cultures that had been pretreated with fibrillar $\mathrm{A} \beta$ or media alone. Donor cultures were assayed for neuronal viability at the time of media transfer, whereas recipient cultures were assayed for neuronal viability $3 \mathrm{~d}$ after treatment with conditioned media. As shown in Figure $7 A$, donor cultures displayed progressive neuronal cell death over the $3 \mathrm{~d}$ of treatment with fibrillar $\mathrm{A} \beta$ and soluble $A \beta$. Interestingly, recipient neuronal cultures that were pretreated with media alone did not demonstrate neurotoxicity after treatment with conditioned media, even when the conditioned media came from donor neuronal cultures displaying $>80 \%$ neuronal cell death (Fig. 7). However, recipient neuronal cultures that were pretreated with fibrillar $\mathrm{A} \beta$ displayed dramatic neuronal cell death under all treatment conditions (Fig. $7 B$ ). The failure of donor culture conditioned media to generate $A \beta$ neurotoxicity in the absence of pretreatment with fibrillar $A \beta$ strongly indicates that neuronal cell death was not caused by the formation of stable, soluble neurotoxic $\mathrm{A} \beta$ species. If stable, neurotoxic $\mathrm{A} \beta$ oligomers mediated this neuronal cell death, then there would not be an absolute requirement for fibrillar $\mathrm{A} \beta$ pretreatment of recipient cultures. These studies provide additional support that nucleationdependent polymerization is an essential component of $\mathrm{A} \beta$ mediated neuronal cell death.

Previous studies have demonstrated that microglia and astrocytes can modulate $\mathrm{A} \beta$-mediated neuronal cell death (Combs et al., 1999; Malchiodi-Albedi et al., 2001; Paradisi et al., 2004). This 

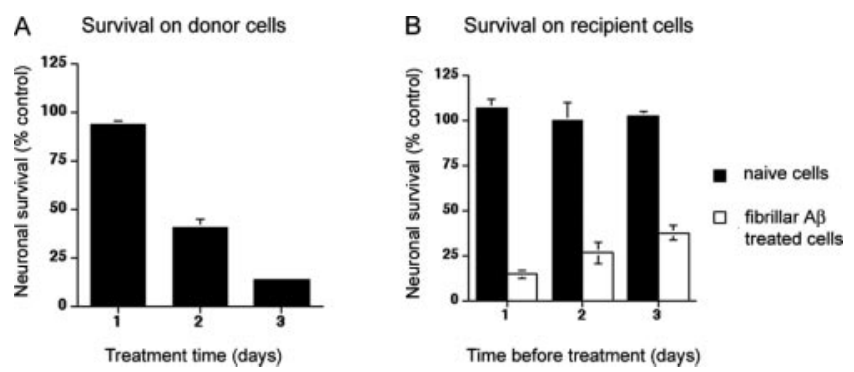

Figure 7. $\quad A \beta$-mediated neuronal cell death generated by nucleation-dependent polymerization cannot be transferred to naive cells. $A$, Human cortical neurons were pretreated with 1 $\mu \mathrm{m}$ fibrillar $A \beta$ for $1 \mathrm{~h}$. Nonadhering fibrillar $A \beta$ was removed by aspiration, followed by three washes with media alone. Soluble $A \beta(40 \mu \mathrm{m})$ was then added to the cultures. After 1, 2, or $3 \mathrm{~d}$ of treatment, the media was removed and transferred to sister cultures. The "donor" cultures were then assayed for neuronal viability (alamarBlue) to assess the extent of neuronal cell death at the time of transfer. $B$, Recipient cultures were pretreated for $1 \mathrm{~h}$ with either $1 \mu \mathrm{m}$ fibrillar $A \beta$ or media alone ("naive" cells). Nonadhering fibrillar $A \beta$ was removed by aspiration, and cultures were treated with conditioned media from donor cultures in $A$. Neuronal viability in "recipient" cultures was then determined using alamarBlue $3 \mathrm{~d}$ after treatment with donor conditioned media. All treatments were in triplicate wells. Error bars indicate \pm SD.

suggests the possibility that the neuronal cell death observed here is caused by soluble toxins released from contaminating glial cells rather than from a direct action of $\mathrm{A} \beta$ polymerization on neurons. Two lines of evidence suggest that the results reported here are not attributable to soluble toxins released by contaminating glial cells. First, the use of B27 as a serum supplement dramatically reduces the number of contaminating microglial cells $(<1 \%)$ and contaminating astrocytes $(<10 \%)$. Second, we were unable to demonstrate neurotoxic activity in the conditioned media obtained in these experiments, strongly suggesting that the neurotoxic effects seen here are not attributable to soluble toxic factors released by contaminating glial cells.

\section{Nucleation-dependent polymerization as a common component of amyloid-mediated neurotoxicity}

Because protein aggregation is associated with a variety of neurodegenerative disorders, it was of interest to determine whether nucleation-dependent polymerization was a common component of the neurotoxic properties associated with other amyloidogenic proteins. In particular, we evaluated whether $\mathrm{A} \beta_{1-42}$, human amylin, and NAC also require both fibrils and soluble peptide to be present to generate neuronal cell death. As shown in Figure 8, the neuronal cell death associated with all three peptides required the presence of both fibrillar and soluble peptide. Although the concentrations of fibrillar and soluble peptide required for neuronal cell death, as well as the method of generating fibrils, varies for different amyloidogenic peptides, a common feature of amyloid-mediated neuronal cell death is the presence of two components, fibrillar and soluble peptide. Thus, nucleation-dependent polymerization appears to be a common mechanistic feature of amyloid-mediated neuronal cell death.

\section{Discussion}

Over the last two decades, accumulating evidence has implicated abnormal protein aggregation as a mechanistic feature of a variety of amyloidogenic disorders, including Alzheimer's disease (Selkoe, 2003). Although significant progress has been made in understanding the structural requirement for $\mathrm{A} \beta$ fibrillogenesis (Harper and Lansbury, 1997), there still remains tremendous uncertainty in regards to the structural requirements for $\mathrm{A} \beta$ mediated neuronal cell death (Caughey and Lansbury, 2003). Studies on the neurotoxic properties of $\mathrm{A} \beta$ have proven difficult
Polymerization-dependent neurotoxicity of additional amyloidogenic proteins

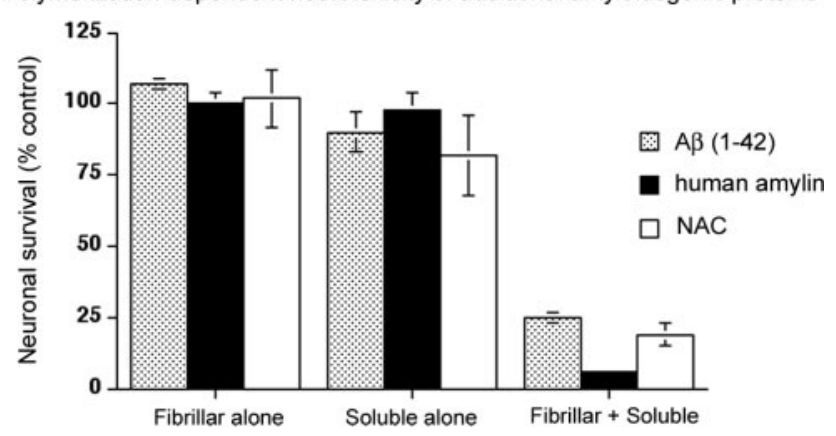

Figure 8. Nucleation-dependent polymerization is a common feature of amyloid-mediated neuronal cell death. Human neuronal cells were treated in basal medium with fibril seed ( $5 \mu \mathrm{m}$ for $A \beta_{1-42}, 1.25 \mu \mathrm{m}$ for human amylin, and $10 \mu \mathrm{m}$ for NAC) or media (for the treatments with soluble peptide alone) for $1 \mathrm{~h}$, nonadhering fibrils were removed by aspiration, and the cells were washed and then treated with soluble peptide $\left(A \beta_{1-42}\right.$ at $20 \mu \mathrm{m}$, human amylin at $5 \mu \mathrm{m}$, and NAC at $12.5 \mu \mathrm{m}$ ) or media (for the fibril alone treatments). Neuronal viability was determined using alamarBlue after $3 \mathrm{~d}$ of treatment with $A \beta_{1-42}$ and human amylin and after $6 \mathrm{~d}$ of treatment with NAC. All treatments were in triplicate wells. Error bars indicate \pm SD.

to interpret because of significant lot-to-lot variability found in biochemically identical synthetic preparations of $\mathrm{A} \beta$ peptides (May et al., 1992) and the use of a variety of culture systems and functional endpoints when assessing the cellular toxicity associated with $\mathrm{A} \beta$ treatment. In this regard, the majority of recent studies on the neurotoxic properties of $\mathrm{A} \beta$ have used the MTT assay, in part because of the high sensitivity and reproducibility of MTT reduction in response to $\mathrm{A} \beta$ treatment (Shearman et al., 1994). Based on findings obtained with the MTT assay, several groups have reported neurotoxicity associated with soluble oligomeric forms of A $\beta$ (Walsh et al., 1999; Dahlgren et al., 2002; Chromy et al., 2003). However, previous studies and the results reported here demonstrate that both fibrillar $\mathrm{A} \beta$ treatment alone and soluble $\mathrm{A} \beta$ treatment alone can cause MTT reduction, without causing overt cell death as measured using the tetrazolium redox dye XTT, alamarBlue, or cellular LDH release (Fig. 2). In contrast, overt neuronal cell death in response to $A \beta$ treatment requires the presence of both fibrillar $\mathrm{A} \beta$ and soluble $\mathrm{A} \beta$ and is tightly correlated with experimental conditions that are known to maintain ongoing $\mathrm{A} \beta$ polymerization.

In addition to an absolute requirement for the presence of both fibrillar $\mathrm{A} \beta$ and soluble $\mathrm{A} \beta, \mathrm{A} \beta$-mediated neuronal cell death shares in a variety of other properties associated with nucleation-dependent polymerization. Previous studies have demonstrated that the rate and extent of $\mathrm{A} \beta$ polymerization is dependent on fibril concentration and monomer concentration (Naiki and Nakakuki, 1996). As demonstrated here, A $\beta$ mediated neuronal cell death is associated with the polymerization of soluble $\mathrm{A} \beta$, most likely along the neuronal cell surface (Fig. 3 and data not shown), and, like nucleation-dependent polymerization, the rate and extent of $\mathrm{A} \beta$-mediated neuronal cell death is directly proportional to the concentration of fibrillar $\mathrm{A} \beta$ and soluble A $\beta$ (Fig. 4).

Another important line of evidence supporting a critical role for $\mathrm{A} \beta$ polymerization as a mechanism for $\mathrm{A} \beta$-mediated neuronal cell death is the observation that shearing fibrils (and thereby increasing the number of free fibril ends) enhances the neurotoxic potency of a given concentration of fibrillar $\mathrm{A} \beta$ (Fig. 5). This observation is consistent with $\mathrm{A} \beta$-mediated neuronal cell death being attributable to growth of fibrils by addition of monomer to the fibril ends, as has previously been demonstrated for nucleationdependent $\mathrm{A} \beta$ polymerization (Harper and Lansbury, 1997). 
An alternative mechanistic explanation for $\mathrm{A} \beta$-mediated neuronal cell death is based on findings that stable or metastable oligomeric forms of $\mathrm{A} \beta$ are generated during the process of $\mathrm{A} \beta$ fibrillogenesis, and that these oligomers or protofibrils are directly toxic to neurons (Hartley et al., 1999; Dahlgren et al., 2002; Chromy et al., 2003). However, we have been unable to demonstrate that neurotoxic soluble or diffusible oligomeric forms of $\mathrm{A} \beta$ are generated during the active process of $\mathrm{A} \beta$-mediated neuronal cell death (Fig. 7). Furthermore, we found that neurotoxic solutions of $\mathrm{A} \beta$ require the presence of both fibrillar $\mathrm{A} \beta$ and soluble $A \beta$ (Figs. 1, 6) suggesting that oligomeric forms of $A \beta$ are not sufficient to generate overt neuronal cell death.

Our review of the published studies on the neurotoxic properties of $\mathrm{A} \beta$ oligomers indicate that most studies have relied on the MTT assay as an indication of neurotoxicity rather than overt neuronal cell death and therefore are not inconsistent with out results. Nonetheless, both protofibrils (Hartley et al., 1999) and amyloid-derived diffusible ligands (Longo et al., 2000) have been reported to cause cell death using methods that do not rely on the MTT assay. However, it is important to note that these studies used experimental conditions that could promote $\mathrm{A} \beta$ polymerization (solutions of $A \beta$ protofibrils or oligomers containing sufficient soluble $\mathrm{A} \beta$ to promote polymerization), suggesting that the findings reported here are not inconsistent with these studies. Based on the issues discussed here on the use of the MTT assay as a reporter of $\mathrm{A} \beta$-mediated neuronal cell death, it is important that future studies do not rely solely on the MTT assay as a reporter of overt neuronal cell death. Recent findings indicate that oligomeric forms of $\mathrm{A} \beta$ can directly inhibit hippocampal longterm potentiation (Walsh et al., 2002; Wang et al., 2002, 2004), suggesting that diffusible oligomeric forms of $\mathrm{A} \beta$ may be involved in subtle alterations of synaptic function and long-term potentiation. Together with our findings that nucleationdependent $\mathrm{A} \beta$ polymerization appears to be essential for mediating overt neuronal cell death, it is likely that different oligomeric forms and processes associated with $\mathrm{A} \beta$ fibrillogenesis may differentially affect synaptic activity, neuronal function, and neuronal cell death in Alzheimer's disease.

The finding that $\mathrm{A} \beta$ polymerization is an essential component of $A \beta$-mediated neuronal cell death has several practical advantages for studies on the neurotoxic properties of amyloidogenic proteins. The studies reported here provide an explanation for why biochemically identical lots of $\mathrm{A} \beta$ have such profound differences in neurotoxic properties. For any given solution of $A \beta$ to be toxic, it must contain quantities and ratios of fibrillar $A \beta$ and soluble $A \beta$ that are sufficient to maintain ongoing polymerization. Stock solutions of $A \beta$ that contain small amounts of fibrillar $\mathrm{A} \beta$ will appear nontoxic or weakly toxic (Fig. $4 B$ ) and require aging to generate sufficient fibril seeds to promote more robust nucleation-dependent polymerization. In contrast, stock solutions of $\mathrm{A} \beta$ that contain large amount of fibrillar $\mathrm{A} \beta$ will rapidly incorporate free $\mathrm{A} \beta$ monomer/oligomers and will lose toxicity once polymerization has terminated as a result of depletion of free A $\beta$ monomer/oligomers (Fig. 6).

Nucleation-dependent polymerization provides a robust and highly reproducible method for studying $\mathrm{A} \beta$-mediated neuronal cell death (Fig. $4 A$ ). In addition, our findings that both fibrillar and soluble peptide are required for neuronal cell death in response to $\mathrm{A} \beta_{1-42}$, NAC, and human amylin (Fig. 8) suggest that nucleation-dependent polymerization may be a common mechanism of amyloid-mediated cell death. Varying the amount and ratio of fibrillar and soluble peptide can precisely control the rate and extent of polymerization and allow an analysis of cellular responses to amyloidogenic peptides under conditions in which the rate and extent of cell death is also precisely controlled. Furthermore, the use of this two-component system allows cellular responses to fibrillar peptide alone or soluble peptide alone to be studied in the absence of overt cell death and thereby provides a method to study more subtle cellular response to amyloidogenic peptides.

The finding that nucleation-dependent polymerization is a critical component of $A \beta$-mediated neuronal cell death provides a mechanistic framework for evaluating both experimental and clinical studies on the role of $A \beta$ in Alzheimer's disease. In particular, our findings on $\mathrm{A} \beta$ polymerization provide a simple explanation for the experimental findings that familial AD mutations lead to increased production or steady-state levels of $\mathrm{A} \beta$ (Selkoe, 2001) or enhanced A $\beta$ protofibril formation (Nilsberth et al., 2001). Elevated levels of soluble $A \beta$ would enhance the rate of $\mathrm{A} \beta$ polymerization and associated neurodegeneration and is consistent with the findings the many of the familial AD mutations lead to early-onset Alzheimer's disease. A role for $\mathrm{A} \beta$ polymerization is also consistent with the finding that the levels of soluble $\mathrm{A} \beta$ correlate most closely with synaptic loss and markers of disease severity in AD brain (Lue et al., 1999; McLean et al., 1999). Higher levels of either fibrillar seed or soluble $A \beta$ in brain parenchyma should result in higher rates of $A \beta$ polymerization and associated neurodegeneration.

The findings reported here have implications for therapeutic approaches to Alzheimer's disease. If $\mathrm{A} \beta$ polymerization is required for neuronal cell death in $\mathrm{AD}$, then any approach that reduces the amount of soluble $\mathrm{A} \beta$ in the brain may be therapeutically valuable, whether or not such treatment actually reverses existing plaque burden. As such, reduction of the amount of soluble $A \beta$ present in the brain parenchyma could dramatically reduce the rate of $\mathrm{A} \beta$ polymerization and thereby the onset and rate of associated neurodegeneration. Similarly, treatments that enhance the clearance of amyloid plaques should also retard the rate of $\mathrm{A} \beta$ polymerization by removing a source of fibrillar $\mathrm{A} \beta$ and thereby protect against nucleation-dependent neuronal cell death. In fact, recent clinical data indicates that antibodies against $\mathrm{A} \beta$ plaques slow cognitive decline in patients with $\mathrm{AD}$ (Hock et al., 2003). Our data indicate that nucleation-dependent polymerization may be a common mechanistic feature of the cellular pathology associated with amyloidogenic proteins. Hopefully, a fuller understanding of the cellular responses to nucleationdependent polymerization will provide novel therapeutic insight into $\mathrm{AD}$ and associated amyloidogenic diseases.

\section{References}

Bozyczko-Coyne D, O’Kane TM, Wu ZL, Dobrzanski P, Murthy S, Vaught JL, Scott RW (2001) CEP-1347/KT-7515, an inhibitor of SAPK/JNK pathway activation, promotes survival and blocks multiple events associated with $\mathrm{A} \beta$-induced cortical neuron apoptosis. J Neurochem 77:849-863.

Caughey B, Lansbury PT (2003) Protofibrils, pores, fibrils, and neurodegeneration: separating the responsible protein aggregates from the innocent bystanders. Annu Rev Neurosci 26:267-298.

Chromy BA, Nowak RJ, Lambert MP, Viola KL, Chang L, Velasco PT, Jones BW, Fernandez SJ, Lacor PN, Horowitz P, Finch CE, Krafft GA, Klein WL (2003) Self-assembly of $A \beta(1-42)$ into globular neurotoxins. Biochemistry 42:12749-12760.

Combs CK, Johnson DE, Cannady SB, Lehman TM, Landreth GE (1999) Identification of microglial signal transduction pathways mediating a neurotoxic response to amyloidogenic fragments of $\beta$-amyloid and prion proteins. J Neurosci 19:928-939.

Cribbs DH, Pike CJ, Weinstein SL, Velazquez P, Cotman CW (1997) All-Denantiomers of $\beta$-amyloid exhibit similar biological properties to all-L$\beta$-amyloids. J Biol Chem 272:7431-7436.

Dahlgren KN, Manelli AM, Stine Jr WB, Baker LK, Krafft GA, LaDu MJ 
(2002) Oligomeric and fibrillar species of amyloid- $\beta$ peptides differentially affect neuronal viability. J Biol Chem 277:32046-32053.

Estus S, Tucker HM, van Rooyen C, Wright S, Brigham EF, Wogulis M, Rydel RE (1997) Aggregated amyloid- $\beta$ protein induces cortical neuronal apoptosis and concomitant "apoptotic" pattern of gene induction. J Neurosci 17:7736-7745.

Garzon-Rodriguez W, Sepulveda-Becerra M, Milton S, Glabe CG (1997) Soluble amyloid A $\beta-(1-40)$ exists as a stable dimer at low concentrations. J Biol Chem 272:21037-21044.

Glenner GG, Wong CW (1984) Alzheimer's disease: initial report of the purification and characterization of a novel cerebrovascular amyloid protein. Biochem Biophys Res Commun 120:885-890.

Hansen MB, Nielsen SE, Berg K (1989) Re-examination and further development of a precise and rapid dye method for measuring cell growth/cell kill. J Immunol Methods 119:203-210.

Harper JD, Lansbury Jr PT (1997) Models of amyloid seeding in Alzheimer's disease and scrapie: mechanistic truths and physiological consequences of the time-dependent solubility of amyloid proteins. Annu Rev Biochem 66:385-407.

Harper JD, Wong SS, Lieber CM, Lansbury Jr PT (1999) Assembly of A $\beta$ amyloid protofibrils: an in vitro model for a possible early event in Alzheimer's disease. Biochemistry 38:8972-8980.

Hartley DM, Walsh DM, Ye CP, Diehl T, Vasquez S, Vassilev PM, Teplow DB, Selkoe DJ (1999) Protofibrillar intermediates of amyloid $\beta$-protein induce acute electrophysiological changes and progressive neurotoxicity in cortical neurons. J Neurosci 19:8876-8884.

Hertel C, Hauser N, Schubenel R, Seilheimer B, Kemp JA (1996) $\beta$-amyloid-induced cell toxicity: enhancement of 3-(4,5-dimethylthiazol2 -yl)-2,5-diphenyltetrazolium bromide-dependent cell death. J Neurochem 67:272-276.

Hock C, Konietzko U, Streffer JR, Tracy J, Signorell A, Muller-Tillmanns B, Lemke U, Henke K, Moritz E, Garcia E, Wollmer MA, Umbricht D, de Quervain DJ, Hofmann M, Maddalena A, Papassotiropoulos A, Nitsch RM (2003) Antibodies against $\beta$-amyloid slow cognitive decline in Alzheimer's disease. Neuron 38:547-554.

Howlett DR, Jennings KH, Lee DC, Clark MS, Brown F, Wetzel R, Wood SJ, Camilleri P, Roberts GW (1995) Aggregation state and neurotoxic properties of Alzheimer $\beta$-amyloid peptide. Neurodegeneration 4:23-32.

Jarrett JT, Lansbury Jr PT (1993) Seeding "one-dimensional crystallization" of amyloid: a pathogenic mechanism in Alzheimer's disease and scrapie? Cell 73:1055-1058.

Kane MD, Schwarz RD, St Pierre L, Watson MD, Emmerling MR, Boxer PA, Walker GK (1999) Inhibitors of V-type ATPases, bafilomycin Al and concanamycin A, protect against beta-amyloid-mediated effects on 3-(4,5-dimethylthiazol-2-yl)-2,5-diphenyltetrazolium bromide (MTT) reduction. J Neurochem 72:1939-1947.

LeVine III H (1997) Stopped-flow kinetics reveal multiple phases of thioflavin $\mathrm{T}$ binding to Alzheimer beta (1-40) amyloid fibrils. Arch Biochem Biophys 342:306-316.

Liu Y, Peterson DA, Kimura H, Schubert D (1997) Mechanism of cellular 3-(4,5-dimethylthiazol-2-yl)-2,5-diphenyltetrazolium bromide (MTT) reduction. J Neurochem 69:581-593.

Longo VD, Viola KL, Klein WL, Finch CE (2000) Reversible inactivation of superoxide-sensitive aconitase in Abeta1-42-treated neuronal cell lines. J Neurochem 75:1977-1985.

Lue LF, Kuo YM, Roher AE, Brachova L, Shen Y, Sue L, Beach T, Kurth JH, Rydel RE, Rogers J (1999) Soluble amyloid- $\beta$ peptide concentration as a predictor of synaptic change in Alzheimer's disease. Am J Pathol 155:853-862.

Malchiodi-Albedi F, Domenici MR, Paradisi S, Bernardo A, Ajmone-Cat MA, Minghetti L (2001) Astrocytes contribute to neuronal impairment in beta A toxicity increasing apoptosis in rat hippocampal neurons. Glia 34:68-72.

May PC, Gitter BD, Waters DC, Simmons LK, Becker GW, Small JS, Robison PM (1992) $\beta$-Amyloid peptide in vitro toxicity: lot-to-lot variability. Neurobiol Aging 13:605-607.

McLean CA, Cherny RA, Fraser FW, Fuller SJ, Smith MJ, Beyreuther K, Bush AI, Masters CL (1999) Soluble pool of A $\beta$ amyloid as a determinant of severity of neurodegeneration in Alzheimer's disease. Ann Neurol 46:860-866.

Morishima Y, Gotoh Y, Zieg J, Barrett T, Takano H, Flavell R, Davis RJ, Shirasaki Y, Greenberg ME (2001) $\beta$-amyloid induces neuronal apoptosis via a mechanism that involves the c-Jun $\mathrm{N}$-terminal kinase pathway and the induction of Fas ligand. J Neurosci 21:7551-7560.
Naiki H, Nakakuki K (1996) First-order kinetic model of Alzheimer's $\beta$-amyloid fibril extension in vitro. Lab Invest 74:374-383.

Nilsberth C, Westlind-Danielsson A, Eckman CB, Condron MM, Axelman K, Forsell C, Stenh C, Luthman J, Teplow DB, Younkin SG, Naslund J, Lannfelt L (2001) The "Arctic" APP mutation (E693G) causes Alzheimer's disease by enhanced A $\beta$ protofibril formation. Nat Neurosci 4:887-893.

Paradisi S, Sacchetti B, Balduzzi M, Gaudi S, Malchiodi-Albedi F (2004) Astrocyte modulation of in vitro beta-amyloid neurotoxicity. Glia 46:252-260.

Patel AJ, Gunasekera S, Jen A, Rohan de Silva HA (1996) $\beta$-Amyloidmediated inhibition of redox activity (MTT reduction) is not an indicator of astroglial degeneration. NeuroReport 7:2026-2030.

Seilheimer B, Bohrmann B, Bondolfi L, Muller F, Stuber D, Dobeli H (1997) The toxicity of the Alzheimer's $\beta$-amyloid peptide correlates with a distinct fiber morphology. J Struct Biol 119:59-71.

Selkoe DJ (2001) Alzheimer's disease: genes, proteins, and therapy. Physiol Rev 81:741-766.

Selkoe DJ (2003) Folding proteins in fatal ways. Nature 426:900-904.

Seubert P, Vigo-Pelfrey C, Esch F, Lee M, Dovey H, Davis D, Sinha S, Schlossmacher M, Whaley J, Swindlehurst C, McCormack R, Wolfart R, Selkoe D, Lieberburg I, Schenk D (1992) Isolation and quantification of soluble Alzheimer's $\beta$-peptide from biological fluids. Nature 359:325-327.

Shearman MS, Ragan CI, Iversen LL (1994) Inhibition of PC12 cell redox activity is a specific, early indicator of the mechanism of beta-amyloidmediated cell death. Proc Natl Acad Sci USA 91:1470-1474.

Shearman MS, Hawtin SR, Tailor VJ (1995) The intracellular component of cellular 3-(4,5-dimethylthiazol-2-yl)-2, 5-diphenyltetrazolium bromide (MTT) reduction is specifically inhibited by $\beta$-amyloid peptides. J Neurochem 65:218-227.

Simmons LK, May PC, Tomaselli KJ, Rydel RE, Fuson KS, Brigham EF, Wright S, Lieberburg I, Becker GW, Brems DN, Li WY (1994) Secondary structure of amyloid- $\beta$ peptide correlates with neurotoxic activity in vitro. Mol Pharmacol 45:373-379.

Soriano FX, Galbete JL, Forloni G (2003) Effect of $\beta$-amyloid on endothelial cells: lack of direct toxicity, enhancement of MTT-induced cell death and intracellular accumulation. Neurochem Int 43:251-261.

Troy CM, Rabacchi SA, Xu Z, Maroney AC, Connors TJ, Shelanski ML, Greene LA (2001) $\beta$-Amyloid-induced neuronal apoptosis requires c-Jun N-terminal kinase activation. J Neurochem 77:157-164.

Tseng BP, Esler WP, Clish CB, Stimson ER, Ghilardi JR, Vinters HV, Mantyh PW, Lee JP, Maggio JE (1999) Deposition of monomeric, not oligomeric, $\mathrm{A} \beta$ mediates growth of Alzheimer's disease amyloid plaques in human brain preparations. Biochemistry 38:10424-10431.

Van Nostrand WE, Melchor JP, Ruffini L (1998) Pathologic amyloid $\beta$-protein cell surface fibril assembly on cultured human cerebrovascular smooth muscle cells. J Neurochem 70:216-223.

Walsh DM, Lomakin A, Benedek GB, Condron MM, Teplow DB (1997) Amyloid beta-protein fibrillogenesis. Detection of a protofibrillar intermediate. J Biol Chem 272:22364-22372.

Walsh DM, Hartley DM, Kusumoto Y, Fezoui Y, Condron MM, Lomakin A, Benedek GB, Selkoe DJ, Teplow DB (1999) Amyloid $\beta$-protein fibrillogenesis. Structure and biological activity of protofibrillar intermediates. J Biol Chem 274:25945-25952.

Walsh DM, Klyubin I, Fadeeva JV, Cullen WK, Anwyl R, Wolfe MS, Rowan MJ, Selkoe DJ (2002) Naturally secreted oligomers of amyloid- $\beta$ protein potently inhibit hippocampal long-term potentiation in vivo. Nature 416:535-539.

Wang HW, Pasternak JF, Kuo H, Ristic H, Lambert MP, Chromy B, Viola KL, Klein WL, Stine WB, Krafft GA, Trommer BL (2002) Soluble oligomers of $\beta$-amyloid (1-42) inhibit long-term potentiation but not long-term depression in rat dentate gyrus. Brain Res 924:133-140.

Wang Q, Walsh DM, Rowan MJ, Selkoe DJ, Anwyl R (2004) Block of longterm potentiation by naturally secreted and synthetic amyloid $\beta$-peptide in hippocampal slices is mediated via activation of the kinases c-Jun $\mathrm{N}$-terminal kinase, cyclin-dependent kinase 5 , and p 38 mitogen-activated protein kinase as well as metabotropic glutamate receptor type 5. J Neurosci 24:3370-3378.

Ward RV, Jennings KH, Jepras R, Neville W, Owen DE, Hawkins J, Christie G, Davis JB, George A, Karran EH, Howlett DR (2000) Fractionation and characterization of oligomeric, protofibrillar and fibrillar forms of betaamyloid peptide. Biochem J 348:137-144.

Yankner BA (1996) Mechanisms of neuronal degeneration in Alzheimer's disease. Neuron 16:921-932. 